\title{
Determinants of Adoption of Wheat Production Technology Package by Smallholder Farmers: Evidences from Eastern Ethiopia
}

\author{
Degefu Kebede $^{1 *}$, Mengistu Ketema ${ }^{1}$, Nigussie Dechassa ${ }^{2}$, Feyisa Hundessa ${ }^{3}$ \\ ${ }^{1}$ School of Agricultural Economics and Agribusiness, Haramaya University, 95, Ethiopia \\ ${ }^{2}$ School of Plant Sciences, Haramaya University, PO Box 138, Dire Dawa, Ethiopia \\ ${ }^{3}$ School of Animal and Range Sciences, Haramaya University, PO Box 138, Dire Dawa, Ethiopia
}

A R T I C LEIN F O

\section{Research Article}

Received 18 October 2016

Accepted 22 January 2017

Keywords:

Wheat technology package

Adoption index

Two-limit Tobit model

Eastern Ethiopia

Hararghe

*Corresponding Author:

E-mail: dgfkebede2009@gmail.com \begin{abstract}
A B S T R A C T
A study was conducted to analyze factors influencing adoption of wheat technology packages by smallholder farmers in Gurawa, Meta and Habro districts in eastern Ethiopia. The analysis was based on a household survey data collected from 136 randomly selected households. A Two-limit Tobit model was used to elucidate factors affecting adoption of technology packages measured based on an index derived from five components of wheat technologies which included row planting, pesticide application, use of improved varieties, and application of inorganic fertilizers, namely, Diammonium Phosphate (DAP) and Urea. Among the variables included in the model, variation in district, gender, age of the household head, education status of the household head, farm size, distance to market, distance to FTC (Farmers' Training Centers), cooperative membership, dependency ratio, and annual income of the households were found to significantly affect the adoption of wheat technology packages. Policy makers, planners and development practitioners should give due attention to these determinants to support smallholder farmers in wheat production and enhance gains derived from it.
\end{abstract}

\section{Introduction}

Agriculture is the core sector of Less Developed Countries (LDCs) in general and Sub-Saharan Africa (SSA) in particular. The situation in Ethiopia, a country with a population of about 100 million, is not different from this fact. More than $85 \%$ of the population derive their livelihood from agriculture. The sector contributes $38.8 \%$ to the Gross Domestic Product (GDP) and a major share in export earnings where exports of coffee, oilseeds, khat (Mild stimulant crop, Chata edulis Forsk.), leather and leather products, pulses, and flower alone contribute more than $70 \%$ (NBE, 2016).

The sector is dominated by smallholder farmers (96\%), where about $56 \%$ of the smallholder farmers possess less than one hectare of land (Taffesse et al., 2012; CSA, 2016). Despite its contribution to the GDP and export earnings, the sector's productivity is very low. In this regard, the research system, along with the other stakeholders, has to play a major role in improving technologies required to enhance agricultural productivity in the country (Biftu et al., 2016; Biftu and Diriba, 2016).

Efforts have been underway by the national agricultural research system since its establishment in 1956 and a number of technologies have been released for the farming community. In spite of these efforts, productivity gains are not as such adequate in the country.
Low level of adoption of technologies is among the major reasons (Spielman et al., 2010; Hailu et al., 2014; Ahmed et al., 2014). Many technology adoption studies emerging in crop sub-sector revealed that the gain from adoption is not satisfactory compared to the expectations, and hence further interventions on factors impeding these are suggested (Kotu et al., 2000; Dixon et al., 2006; Dercon and Christiaensen, 2011; Asfaw et al., 2012; Shiferaw et al., 2014; Ahmed, 2015; Jaleta et al., 2016; Yigezu et al., 2015; Beshir, 2016; Biftu and Diriba, 2016; Hagos, 2016; Seymour et al., 2016).

The study areas, East Hararghe and West Hararghe zones in eastern Ethiopia, are known for cultivation of many crops which include, among others, cereals such as maize, sorghum, wheat, pulses, etc. Moreover, khat, and vegetables are commonly grown in the area.

Similar to the other parts of the country, achieving food security is a bottleneck in the study areas. Though contributors for food insecurity are similar with that in other regions, high population pressure, small landholdings and fragmentation, frequent variability in climate variables (like temperature and rainfall), lowmoisture stress, and lack of efficient market opportunities are among the most important obstacles exacerbating the situation (Nigussie Dechassa et al., 2012). Low level of 
adoption of crop technologies is also among the major factors contributing to low productivity (Mulatu et al., 2005; Cavatassi et al., 2011). This low level of adoption holds true for wheat technologies as well.

Wheat is among the most important staple food crops grown in Ethiopia. In 2015/16 main season, the total area under wheat production was 1.66 million ha while the total production was about 4.2 million tons. In East and West Hararghe, the total area under wheat production was 18289.94 ha and 4143.26 ha, respectively (CSA, 2016). The zonal average productivity of wheat is 2.1 tons/ha for East Hararghe and 1.9 tons/ha for West Hararghe Zone which are less than the national average of 2.5 tons/ha (CSA, 2015). The figures are by far less than the world average of 3.05 tons/ha for the year 2014/15 (Statista, 2017). This is related to the low level of adoption of wheat technologies.

The Ethiopian government has been promoting a package-driven extension that combines credit, fertilizers, improved seeds, and better management practices (Bingxin et al., 2011). Given this scenario, technology adoption studies should take in to account package-based adoptions of technologies. For instance, wheat technology packages in East Hararghe and West Hararghe zones include improved planting methods (row planting), improved varieties, appropriate use of inorganic fertilizers, and applications of pesticides. However, many of the adoption studies focused on a single component of the technology package (Croppenstedt et al., 2003; Asfaw et al., 2011; Beshir et al., 2012; Ahmed, 2015; Biftu et al., 2016; Amare and Bekele, 2016). In such cases, it is difficult to have a clear understanding of the adoption of technology packages. Other existing studies on wheat technology adoption are broad and at national level (eg. Shiferaw et.al., 2014; Jaleta et al., 2015). These, in turn, have a limitation in terms of targeting solutions towards addressing policy interventions in specific contexts.

The purpose of this study was, therefore, to identify the factors that dictate adoption of wheat technology packages at household level and to estimate the relative importance of the factors.

\section{Material and Method}

\section{Description of the Study Area}

The study was conducted in three districts, Gurawa and Meta districts in East Hararghe zone and Habro district in West Hararghe zone in eastern Ethiopia.

Gurawa district: Gurawa is one of the districts in East Hararghe zone with high agricultural production potential. The altitude of the district ranges from 500 to 3230 meters above sea level. The district has an estimated total population of 300661 (CSA, 2013). The district is known for its production of staple crops (wheat, barley and Irish potato) and fruit (apple) (Nigussie Dechassa et al., 2012).

Meta district: Meta is also one of the districts in the East Hararghe zone. Meta district, apart from its high cereal production potential (like wheat production), is known for its potent for production of cash crops such as coffee and khat. A projected total population for this district, for the year 2016, was about 318458 of whom 160334 were men and 158124 were women (CSA, 2013).

Habro district: Habro is one of the 14 districts located in West Hararghe zone. The district has an estimated total population of 244444 of whom 126176 were men and 118268 were women (CSA, 2013). The agro-ecology of the district comprises highland (19\%), mid-altitude $(50 \%)$, and lowland $(31 \%)$ areas. The mean annual rainfall of the district is $1010 \mathrm{~mm}$ and the annual temperature ranges from $5-32^{\circ} \mathrm{C}$.

\section{Sampling Procedure}

A cross-sectional study design was used. Household survey questionnaire was administered to collect data from the smallholder farmers drawn from the study area. Multistage sampling technique was employed. The steps involved were purposive selection of the three districts which are known for their wheat production, followed by random selection of two representative Peasant Associations (PA, A peasant association is the smallest administrative unit of the rural population in Ethiopia) from each district, which makes a total of six PAs. A total of 136 household heads were randomly chosen from a population of wheat growing farmers as the final respondents. Given the relatively homogenous nature of the population in terms of resource ownership and livelihood structure, a sample of 136 is assumed to represent the smallholder wheat growers in the area.

\section{Data Sources and Methods of Data Collection}

Primary data were collected using a structured questionnaire that comprises information related to household socioeconomic characteristics (farm characteristics, production, income, institutional factors/services and technology utilization, among others). The survey was conducted during the 2015/2016 production period. Additional information like recommended fertilizer rates were collected from secondary sources.

\section{Specification of Econometric Model}

Selection of econometric model requires taking in to account the nature of the dependent variable, among others. The dependent variable, the adoption index, is a continuous value between zero and one in this study. A dependent variable which bears a zero value for a significant portion of the observations requires a censored regression model (Two-limit Tobit model). Such censored regression is preferred because it uses data at the limit as well as those above the limit to estimate regression. Following the work of Maddala (1997), the Tobit model can be derived by defining a new random variable $y^{*}$ that is a function of a vector of variables.

The equation for the model is constructed as:

$$
Y^{*}=X_{i} \beta_{i}+\epsilon_{i}
$$


Where $Y^{*}$ is unobserved for values less than 0 and greater than 1 (called a latent variable). It represents an index for wheat technology package adoption, $X_{i}$ represents a vector of explanatory variables, $\beta_{\mathrm{i}}$ is a vector of unknown parameters, and $\varepsilon \mathrm{i}$ is the error term.

Through representing yi (selected agricultural technology adoption index) as the observed dependent variable, the two limit Tobit model can be specified as:

$$
y i=\left\{\begin{array}{ccc}
0 & \text { if } y i * \leq 0 \\
y * \text { if } 0<y i *<1 & 1 \\
1 & \text { if } y i *>1
\end{array}\right\}
$$

Censored regression models (including the standard Tobit model) are usually estimated by the Maximum Likelihood (ML) method. The log likelihood function is specified with an assumption that the error term $\varepsilon$ follows a normal distribution with mean 0 and variance $\sigma^{2}$. The Tobit coefficients can be interpreted as coefficients of a linear regression model.

In line with this, determinants of adoption of wheat technology package were investigated by using Tobit model. The dependent variable in the model is index value ranging from 0 to 1 . A value of 0 indicates nonadopter, index value 1 represents the full adopter of the technology component (adopted without discontinuity), and the values between 0 and 1 indicate the level of the adoption within the range of the Tobit Model Limit.

\section{Definition of Variables and Working Hypothesis}

The dependent variable: The dependent variable for wheat technology adoption package was an index computed from the use and intensity of use of technologies related to variety, pesticide, row planting, Di-Ammonium Phosphate (DAP) and Urea in wheat production. It is a weighted index, censored between 0 and 1, which is computed based on these five technology components as follows.

$$
\text { Adop. } \text { index }=\frac{\text { Imp.var. }+ \text { DAP }+ \text { Urea }+ \text { Pest } .+ \text { Row }}{5}
$$

Where improved variety use intensity is the proportion of wheat farm covered by improved variety; DAP use intensity is the ratio of the actual rate of DAP applied on a wheat field to the recommended rate of DAP (i.e. $100 \mathrm{~kg}$ per ha); Urea use intensity is the ratio of actual rate of Urea applied on a wheat field to the recommended rate of Urea (i.e. $125 \mathrm{~kg}$ per ha); pesticide use is whether the farmers have used herbicides, insecticides, and fungicides; and row planting is whether the farmers have used nearly or exactly the recommended spacing between rows and plants.

Explanatory variables: As per the theoretical justifications and prior literature, a number of explanatory variables have been hypothesized to influence the adoption of agricultural technologies, wheat technology in particular (Feder et al., 1985). Accordingly, attempts were made to include several important and relevant variables suspected to be the most important factors in adoption of wheat technology package by smallholder farmers. The potential explanatory variables hypothesized and included in the Tobit model specification for wheat technology package are those indicated in Table 1.

\section{Results and Discussions}

Descriptive Results

Household characteristics: About $23 \%$ of the respondents are female headed households. The intention here was to consider the relevance of gender in technology adoption as women play a key role in most agricultural systems. The average age of sample household head was 38.82 (for combined districts) with a standard deviation of 10.37 . About $63.5 \%$ of the sampled household heads were literate. Dependency ratio, as proxy for availability of labor for farming activity indicates that more dependent family members are observed compared to the active and working labour family members in the study areas (about 33\%).

Farm characteristics: Average land holding in the study area is less than a hectare. Accordingly, on average, 0.57 ha were the average landholding and sample household farmers operate on about 3 plots.

\begin{tabular}{|c|c|c|c|}
\hline Variables & Type of Variable & Description of the variable & Exp. sign \\
\hline District & Categorical & Study districts, Gurawa, Meta and Habro & $+/-$ \\
\hline Sex of the HH head & Dummy & 1 if the household head is male, 0 otherwise. & $+/-$ \\
\hline Age & Continuous & Age of household head (in years) & + \\
\hline Education & Dummy & Educational status, 1 if literate, 0 otherwise & + \\
\hline Distance to market & Continuous & Home-farm distance in kilometers & - \\
\hline Distance from FTC & Continuous & Distance from FTC in kilometers & - \\
\hline Number of plots & Discrete & Number of plots owned & $+/-$ \\
\hline Membership to cooperative & Dummy & 1 if the household is a member, 0 otherwise & + \\
\hline Extension contact & Categorical & $\begin{array}{l}\text { Frequencies of extension contact: a value } 0,1,2,3,4 \\
\text { and } 5 \text { for no contact, every day, every week, every } \\
\text { fortnight, and every month, respectively }\end{array}$ & $+/-$ \\
\hline Farming experience & Continuous & Household's farm experience in years & + \\
\hline Farm size & Continuous & Total land holding in ha & + \\
\hline Dependency ratio & Continuous & $\begin{array}{l}\text { Dependent members }(<15 \text { years } \&>64 \text { yrs }) \text { to } \\
\text { working members }(15-64 \text { yrs }) \text { in the household }\end{array}$ & - \\
\hline Annual income & Continuous & Household's annual income in Ethiopian currency (Birr) & + \\
\hline
\end{tabular}

Table 1 Summary of the independent variables hypothesized to affect adoption of wheat technology packages 
Income: On average, higher annual income was observed in Habro district (about 24,380 Birr) followed by Meta district (about 16,450 Birr) and Gurawa district (about 12,660 Birr).

Institutional factors and services: The survey result shows that $50 \%$ of the respondent households were members to cooperatives in the study area. District wise, about $62 \%, 54 \%$ and $34 \%$ of the sampled smallholders were members to cooperatives in Gurawa, Habro and Meta districts in that order. This difference in membership across districts is statistically significant at $1 \%$ level $\left(\chi^{2}=15.1\right)$. The average distance of the household from FTC was found to be 1.72 kilometers.

Crop technology utilization: Wheat production technology package components includes use of pesticides, use of row planting, improved variety use, and inorganic fertilized usage (DAP and Urea use). Accordingly, about $6 \%$ of the sample households used pesticides. Row planting use level in wheat was about $46 \%$. On average, out of total area under wheat production in the study districts, about $49 \%$ was allotted for improved variety while the remaining was covered by local varieties. DAP use intensity result shows that sampled farmers used about $69 \%$ of the recommended level (recommendation rate is $100 \mathrm{~kg} \mathrm{DAP} \mathrm{ha}{ }^{-1}$ ). Similarly, urea use intensity result shows that the sampled farmers used $62 \%$ of the recommended rates for wheat (i.e. $125 \mathrm{~kg}$ Urea ha $^{-1}$ ). The result shows underutilization of these fertilizers and that could be in turn reflected in yield gaps. While considering all the five components of wheat technology packages under this study (i.e. use of pesticide, row planting, use intensity of improved variety, application of DAP and urea), the overall adoption index is about $48 \%$ of the package level of wheat production in the study area.

\section{Econometric Results}

Determinants for adoption of technology packages: The overall variance inflation factors (VIF) of all independent variables in the Tobit model is less than 10 indicating that multicolliniarity was not a problem with the finally implemented model. Therefore, the relationship between the adoption index (dependent variable) and predictor variables were computed by employing a two-limit Tobit model. The models also demonstrated a good fit at $1 \%$ level of significance which can be observed from $F$ statistic.

The Two-limit Tobit model result shows that socioeconomic factors, including variation in district (location), gender of the household head, age of household head, distance to market, distance to FTC, membership to cooperatives, farm size, dependency ratio, and annual income were significant determinants of adoption of wheat technology package at different levels of significance (Table 6).

Table 2 Summary statistics of the households (categorical variables) (\%)

\begin{tabular}{|c|c|c|c|c|c|}
\hline Variables & Gurawa & Meta & Habro & Total & $\chi^{2}$ (Total) \\
\hline \multicolumn{6}{|c|}{ Gender of household head } \\
\hline Female & 9.4 & 13.5 & 14.6 & 12.5 & \multirow{2}{*}{1.33} \\
\hline Male & 90.6 & 86.5 & 85.4 & 87.5 & \\
\hline \multicolumn{6}{|c|}{ Education (literacy) status of household head } \\
\hline Illiterate & 37.5 & 32.3 & 39.6 & 36.5 & \multirow{2}{*}{1.17} \\
\hline Literate & 62.5 & 67.7 & 60.4 & 63.5 & \\
\hline \multicolumn{6}{|c|}{ Membership to Cooperative } \\
\hline Non member & 38.5 & 65.6 & 45.8 & 50.0 & \multirow{2}{*}{$15.08 * * *$} \\
\hline Member & 61.5 & 34.4 & 54.2 & 50.0 & \\
\hline \multicolumn{6}{|c|}{ Frequency of Extension contact } \\
\hline No contact & 6.9 & 2.4 & 3.2 & 4.1 & \multirow{5}{*}{$58.19 * * *$} \\
\hline Daily contact & 4.6 & 4.8 & 10.5 & 6.8 & \\
\hline Weekly contact & 39.1 & 14.3 & 52.6 & 36.1 & \\
\hline Fortnight & 31.0 & 20.2 & 12.6 & 21.1 & \\
\hline Monthly contact & 18.4 & 58.3 & 21.1 & 31.9 & \\
\hline
\end{tabular}

Table 3 Summary statistics for pesticide and row planting use (\%)

\begin{tabular}{l|cccccccccc}
\hline \multirow{2}{*}{ Technology type } & \multicolumn{2}{|c}{ Gurawa } & \multicolumn{2}{c}{ Meta } & \multicolumn{2}{c}{ Habro } & \multicolumn{2}{c}{ Total } & $\chi^{2}$ \\
\cline { 2 - 8 } & User & NU $^{*}$ & User & NU & User & NU & User & NU & (Total) \\
\hline Pesticides use & 5.9 & 94.1 & 24.7 & 75.3 & 50.0 & 50.0 & 17.5 & 82.5 & $8.84^{* *}$ \\
Row planting use & 72.5 & 27.5 & 23.3 & 76.7 & 50.0 & 50.0 & 45.6 & 54.4 & $29.65^{* * *}$ \\
\hline
\end{tabular}

*NU- non user,

Table 4 Summary statistics for improved varieties and fertilizers

\begin{tabular}{cc|ccc|ccc}
\hline \multicolumn{2}{c|}{ Improved variety uses intensity } & \multicolumn{3}{|c|}{ DAP uses intensity } & \multicolumn{3}{c}{ Urea uses intensity } \\
\hline Proportion & SD & Proportion & Mean & SD & Proportion & Mean & SD \\
\hline 0.49 & 0.49 & 100 & 0.69 & 0.36 & 125 & 0.62 & 0.35 \\
\hline
\end{tabular}


Table 5 Summary statistics of the sample households (continuous variables)

\begin{tabular}{l|cccccccc}
\hline \multirow{2}{*}{\multicolumn{1}{c}{ Variables }} & \multicolumn{2}{c}{ Gurawa Dist. } & \multicolumn{2}{c}{ Meta Dist. } & \multicolumn{2}{c}{ Habro Dist. } & \multicolumn{2}{c}{ Total } \\
\cline { 2 - 8 } & Mean & SD & Mean & SD & Mean & SD & Mean & SD \\
\hline Age of household head & 36.45 & 9.84 & 40.02 & 10.36 & 40 & 10.59 & 38.82 & 10.37 \\
Farming Experience (years) & 17.72 & 9.29 & 19.19 & 9.18 & 21.09 & 9.52 & 19.33 & 9.40 \\
Total land holding (size) ha & 0.33 & 0.16 & 0.39 & 0.26 & 0.99 & 0.65 & 0.57 & 0.51 \\
Number of plots owned & 2.57 & 0.95 & 2.64 & 1.09 & 2.79 & 1.19 & 2.67 & 1.08 \\
Distance to nearest market (km) & 2.11 & 2.45 & 4.81 & 2.12 & 3.59 & 2.19 & 3.49 & 2.51 \\
Distance to FTC (km) & 1.43 & 1.22 & 2.01 & 2.19 & 1.72 & 1.36 & 1.72 & 1.66 \\
Dependency ratio & 1.44 & 0.88 & 1.06 & 0.81 & 1.48 & 1.05 & 1.33 & 0.93 \\
Annual income (Birr. '000') & 12.66 & 10.69 & 16.45 & 13.35 & 24.38 & 23.45 & 17.83 & 17.40 \\
Wheat adoption index & 0.49 & 0.21 & 0.46 & 0.27 & 0.59 & 0.51 & 0.48 & 0.25 \\
\hline
\end{tabular}

Variations in district explained the difference in adoption of wheat technology package among these areas. This could be related to the natural suitability of the agroecology of the locations and differences in potentiality of the districts to wheat production, among others. Accordingly, the model output shows that farmers located in wheat potential location like Gurawa district are found to be better adopters of wheat technology package compared to the farmers in Habro district. This difference was statistically significant at $10 \%$ significance level. The result conveys the message that location matters in wheat technology adoption.

Sex of the household head was found negatively influencing adoption of the technology. The result indicated that if the household head is male, the chances of adoption of wheat technology package decreases by the factor of 0.116 as compared to a household headed by female, and the result was statistically significant at $10 \%$ level of significance. This finding is in congruence with findings of Asfaw et al. (2012). Contrary to this finding, Doss et al. (2003), and Bingxin and Alejandro (2014) found that male-headed households were found to be more likely to use improved wheat varieties than female headed households.

The effect of the age of household head on adoption was statistically significant at $1 \%$ level. The result revealed that a year increase in age of household head, results in an increase in the chance of wheat technology package adoption by a factor of 0.008 , other factors kept constant. This means the older generation is more likely adopters of wheat technology package as compared to their counter younger farmers. The reason could be the possibility for capitalization of information and knowledge about the technology packages through time (as the age is getting older). This result is congruent with the study by Hailu (2008) and Asfaw et al. (2012). Similarly, Hagos (2016) and Kaleb and Workneh (2016) found a positive influence of age on agricultural technology adoption in general. On the other hand, Bingxin et al. (2011), Asfaw et al. (2011), Hailu et al. (2014) and Jaleta et al. (2015) found a negative influence of age on adoption of technology confirming the younger age groups are adopters compared to their counterpart, the elders.

Distance from market negatively influenced adoption of wheat technology package. The result indicates that a kilometer increase in distance from market leads to a decrease in the likelihood of adoption of wheat technology packages by a factor of 0.023 , other factors kept constant. The result was statistically significant at $5 \%$ level. This result is in line with the findings of other similar studies (e.g. Tesfaye et al., 2001; Asfaw et al., 2011) which showed that market is an important institution that dictates adoption of wheat technology package at a household level. Also the studies by Beshir et al. (2012) and Gebresilassie and Bekele (2015) confirmed similar results.

Proximity to farmers' training center (FTC), however, explained adoption of wheat technology package the other way round to distance from the market. Farmers residing at a farther distance from an FTC were found to be better adopters of wheat technology packages compared to those residing at a distance located closer to an FTC. Accordingly, a kilometer increase in farmers' distance from FTC results in an increase in adoption of wheat technology by a factor of 0.018 , keeping other factors constant and it is statistically significant at $10 \%$ level. This result is in line with results of a prior study conducted by Asfaw et al. (2012) which had revealed a negative influence of distance from office of agriculture on technology adoption. Although a clear reason is unknown in this relation, we expect that it could happen due to the fact that under the current context of the study areas, the level of technology demonstration, promotion and services provided for farmers in this regard at FTCs could be inadequate as far as wheat is concerned.

Being a member of a cooperative institution was found to positively influence adoption of wheat technology packages. Other factors kept constant, being members of cooperatives was found to affect farmers' likelihood of the package adoption by the factor of 0.134 , and the result was statistically significant at $1 \%$ level. The result conveys the message that cooperatives are among the strongest social institutions that play crucial roles in adoption of wheat technology packages, and also findings from the studies by Tesfaye et al. (2001), Abebaw and Haile (2013) and Ahmed (2015) are consistent with this result.

The econometric model output for farm size shows that farm size is among the major positive determinants of wheat technology package adoption and the result is statistically significant at 5\% level. Tesfaye et al. (2001) and Shiferaw et al. (2014) similarly observed a positive influence of farm size where the chance of adoption of the 
technology by and large is likely to occur as land size increases. Accordingly, allocation of one more hectare of the farm land to wheat production increases adoption of wheat technology package by a factor of 0.285 , other factors kept constant. This could be expected because in reality the economic gain (productivity and profitability) from production of crops like wheat is better on relatively large size of land than on small plots of land unlike the cases for other crops such as potato and other vegetables.

Labor availability, along with the structure of the working age within a household was one of the most important determinants of agricultural technology adoption, captured in terms of dependency ratio (i.e. the ratio of dependent family member to the active working age). We found that dependency ratio was statistically significant at $10 \%$ level in predicting adoption of wheat technology package. The result is, in fact, against our hypothesis and this could happen because technologies have different labor characteristics; some save labor, while others significantly demand it, and wheat technologies, unlike other crop technologies do not require intensive labor.

The output for annual income shows that it was among the determinants of adoption of wheat technology package in the study area. The result is statistically significant at 5\% level. Accordingly, an increase in household annual income by one Birr would lead to an increase in the likelihood of wheat technology adoption by a factor of 0.004 , keeping other factors constant. This could happen because a household with sufficient annual income could not be financially constrained and prohibited from the timely use of the wheat technology packages. This result agrees with the findings of Beshir et al. (2012).

Table 6 Estimates of the Two-limit Tobit model for adoption of wheat technology packages

\begin{tabular}{l|ccc}
\hline \multicolumn{1}{c|}{ Variables } & Coefficient & Robust standard error & $\mathrm{t}$ - value \\
\hline District: Gurawa district is a reference group & & & 0.058 \\
$\quad$ Metta district & 0.044 & 0.223 & -1.69 \\
$\quad$ Habro district & $-0.377^{*}$ & 0.694 & -1.68 \\
Sex of household head & $-0.116^{*}$ & 0.003 & 2.74 \\
Age of household head (years) & $0.008^{* * *}$ & 0.044 & 1.30 \\
Education of household head (dummy) & 0.057 & 0.011 & -2.13 \\
Distance to market (km) & $-0.023^{* *}$ & 0.009 & 1.89 \\
Distance to FTC (km) & $0.018^{*}$ & 0.033 & -1.64 \\
Number of plots owned & -0.054 & 0.050 & 2.67 \\
Membership to cooperative(dummy) & $0.134^{* * *}$ & & -1.62 \\
Extension contact: No contact is a reference group & & 0.117 & -0.47 \\
$\quad$ Every day & -0.191 & 0.081 & 0.23 \\
$\quad$ Every week & -0.038 & 0.087 & -0.71 \\
$\quad$ Every fortnight & 0.020 & 0.099 & -0.49 \\
$\quad$ Every month & -0.070 & 0.004 & 2.41 \\
Farming experiences (years) & -0.002 & 0.118 & 1.85 \\
Farm size (ha) & $0.285^{* *}$ & 0.032 & 2.37 \\
Dependency ratio & $0.060^{*}$ & 0.002 & 1.27 \\
Annual income ('000' Birr) & $0.004^{* *}$ & 0.152 & \\
Constant & 0.194 & 6.89 & \\
Log likelihood & $6.49 * * *$ & 110 & \\
LR Chi2 (17) & & & \\
Number of observation (N) & & &
\end{tabular}

Note: $* * *, * *$ and $*$ implies statistical significance at 1,5 , and $10 \%$ levels, respectively.

\section{Conclusions}

The study analyzed the determinants of adoption of wheat technology package using the Two-limit Tobit econometric model. The study was based on data collected from 136 wheat growing farm households drawn from Gurawa, Meta and Habro districts of East Hararghe and West Hararghe zones.

Descriptive results revealed that the dependency ratio in the area was high, which have implication for labor availability for agriculture. On the other hand, the average land holding in the area was less than a hectare (about $0.57 \mathrm{ha}$ ). Level of utilization of wheat technology package in the study area was only about $48 \%$.
The econometric models revealed that variation in districts, gender of household head, age of the household head, education status of the household head, farm size, distance to market, distance to FTC, membership to cooperative, dependency ratio, and annual income of the household dictated the adoption of wheat technology package significantly. For instance, elders were found to be better adopters of wheat technology package than the juniors, which could be related to less labor demanding aspects of wheat technology package. Farm size explained package of wheat technology adoption positively which could be related to possible gains from comparative advantage from intensification of production and productivity level per a given farm size. Distance to 
market negatively and significantly influenced the adoption of wheat technology package in the study area. However, distance to FTC positively and significantly explained the adoption.

Furthermore, membership to cooperatives predicted positively and significantly the adoption of wheat technology package. Similarly, both dependency ratio and income of the household positively explained the adoption of wheat technology package.

The following are implications drawn from this study in relation to adoption of wheat technology package in the study area.

Institutions like cooperatives play an enormous role in disseminating technologies such as improved seeds and fertilizers, and in providing information for farmers in order to disseminate technologies. Further attempts to address farmers through cooperatives, therefore, play great roles in enhancing adoptions of technologies.

Use of mineral fertilizers such as DAP and urea are still lagging behind the recommendations. Therefore, attempts in bridging such gap by encouraging farmers to stick to the recommended levels could maximize productivity from crops like wheat.

Technologies require specific locations that favors the potential effects on productivity. It is, therefore, necessary to consider location-specific factors while disseminating technologies. Improvements in rural infrastructure (especially rural roads) should be further strengthened and it is an area of further attention to enable farmers to transact in both factors and product markets in a reasonable way.

It is crucial to consider gender-related issues and their roles in technology adoption, since some of the technologies by their very nature fit specific gender groups of the community (e.g. wheat technology package was better adopted by female-headed households than by male-headed households in this study).

Encouraging activities that boost and diversify farm income and financially supporting smallholder farmers for enhancing adoption of technologies could also be crucial measures. Acknowledging, the dynamisms in technology adoption and diffusions, similar research should be conducted after certain years on the determinants of wheat technology adoption in the study area.

\section{Acknowledgements}

The authors thank the CASCAPE (Capacity building for scaling up of evidence-based best practices in agricultural production in Ethiopia) project, which was finanacially supported by The Government of the Netherlands and coordinated by the Royal Netherlands Embassy in Addis Ababa, and hosted by Haramaya University for covering all costs related to the research work.

\section{References}

Abebaw D, Haile HD. 2013. The impact of cooperatives on agricultural technology adoption: Empirical evidence from Ethiopia. Food policy. 38: 82-91. DOI: http://dx.doi.org/10.1016/j.foodpol.2012.10.003
Ahmed H, Lemma Z, Endrias G. 2014. Technical efficiency of maize producing farmers in Arsi Negelle, Central Rift Valley of Ethiopia: Stochastic Frontier Approach. J. Agriculture and Forestry. 60 (1): 157-167.

Ahmed H. 2015. Adoption of multiple agricultural technologies in maize production of the Central Rift Valley of Ethiopia. Studies in Agricultural Economics. 117: 162-168. DOI: http://dx.doi.org/10.7896/j.1521

Asfaw S, Shiferaw B, Simtowe F, Haile MG. 2011. Agricultural technology adoption, seed access constraints, and commercialization in Ethiopia. Journal of Development and Agricultural Economics. 3(9): 436-447. Available at SSRN: https://ssrn.com/abstract=2056976

Asfaw S, Kassie M, Simtowe F, Leslie L. 2012. Poverty reduction effects of agricultural technology adoption: a micro-evidence from rural Tanzania. The Journal of Development Studies. 48(9): 1288-1305. DOI: http://dx.doi.org/10.1080/ 00220388. 2012.671475

Beshir H, Emana B, Kassa B, Haji J. 2012. Determinants of chemical fertilizer technology adoption in north eastern highlands of Ethiopia: the double hurdle approach. JREIF. 1(2): 39-49. Available online at http://www.interesjournals.org/JREIF

Beshir H. 2016. Technical efficiency measurement and their differential in wheat production: The case of smallholder farmers in South Wollo. IJEBF. 4 (1): 1-16. Available online at http://ijebf.com

Biftu A, Diriba B. 2016. Pre-scaling up of bread wheat variety (Danda'a) through FRG/FREG in Bale and West Arsi zones of Oromia national regional state, Ethiopia. Scientific Journal of Crop Science. 5(3): 104-115. Available online at: http://sjournals.com/index.php/SJCS/article/view/2147

Biftu A, Diriba B, Bayisa T, Getachew F. 2016. Participatory demonstration and evaluation of bread wheat technologies: The experience of FRG/FREG approach in Bale and West Arsi zones of Oromia national regional state, Ethiopia. Scientific Journal of Crop Science, 5(3): 90-103. Available at: http://www.sjournals.com/index.php/SJCS/article/view/2146

Bingxin Y, José F, Sinafikeh A. 2011. Cereal Production and Technology Adoption in Ethiopia. Development Strategy and Governance Division. Int. Food Policy Res. Inst. 36p.

Bingxin Y, Alejandro N. 2014. Fertilizer Adoption in Ethiopia cereal production. J. Dev. Agric. Econ. 6(7): 318 - 337.

Cavatassi R, Lipper L, Narloch U. 2011. Modern variety adoption and risk management in drought prone areas: insights from the sorghum farmers of Eastern Ethiopia. The Journal of the International Association of Agricultural Economists. 42(3): 279-292. DOI: http://dx.doi.org/10.1111/j.1574-0862. 2010.00514.x

Croppenstedt A, Demeke M, Meschi M. 2003. Technology adoption in the presence of constraints: the case of fertilizer demand in Ethiopia. Review of Development Economics. 7(1), 58-70. DOI: http://dx.doi.org/10.1111/1467-9361.00175

CSA (Central Statistical Authority). 2013. Population projection of Ethiopia for all regions at Wereda level from 2014 - 2017. Central Statistical Agency, Addis Ababa, Ethiopia.

CSA (Central Statistical Authority). 2015. Agricultural sample survey 2014/15. Volume I. Report on area and production of major crops for private peasant holdings, meher season. Statistical bulletin 578. Central Statistical Agency, Addis Ababa, Ethiopia.

CSA (Central Statistical Authority). 2016. Agricultural sample survey 2015/16. Volume I. Report on area and production of major crops for private peasant holdings, meher season. Statistical bulletin 584. Central Statistical Agency, Addis Ababa, Ethiopia.

Dercon S, Christiaensen L. 2011. Consumption risk, technology adoption and poverty traps: Evidence from Ethiopia. Journal of Development Economics. 96: 159-173. DOI: http://dx.doi.org/10.1016/j.jdeveco.2010.08.003

Dixon J, Nalley L, Kosina P, La Rovere R, Hellin J, Aquino P. 2006. Adoption and economic impact of improved wheat varieties in the developing world; centenary review. The Journal of Agricultural Science. 144: 489-502. DOI: https://dx.doi.org/10.1017/S0021859606006459 
Doss C, Mwangi W, Verkuijl H, Groote H. 2003. Adoption of maize and wheat technologies in eastern Africa: a synthesis of the findings of 22 case studies. CIMMYT economics working paper 03-01. Mexico, D.F.: CIMMYT.

Feder E, Just RE, Zilberman D. 1985. Adoption of agricultural innovations in developing countries: A survey. EDCC. 33: 255298.

Gebresilassie L, Bekele A. 2015. Factors determining allocation of land for improved wheat variety by smallholder farmers of northern Ethiopia. J. Dev. Agric. Econ. 7(3): 105-112. DOI: https://dx.doi.org/10.1086/451461

Hagos BG. 2016. Impact of Agricultural technology adoption of smallholder farmers on wheat yield: Emprical evidence from Southern Tigrai state of Ethiopia. J. Agric. Ext. Rural Dev. 8(10): 211-223. DOI: https://dx.doi.org/10.5897/ JAERD2016.0786

Hailu BK, Abrha BK, Weldegiorgis KA. 2014. Adoption and impact of agricultural technologies on farm income: Evidence from southern Tigray, northern Ethiopia. IJFAEC. 2(4): 91-106.

Hailu BA. 2008. Adoption of improved tef and wheat production technologies in crop livestock mixed systems in northern and western Shewa Zones of Ethiopia. PhD Thesis, Faculty of Natural \& Agricultural Science, University of Pretoria.

Jaleta M, Kassie M, Marenya P. 2015. Impact of improved maize variety adoption on household food security in Ethiopia: an endogenous switching regression approach. Paper presented on Int. conference of agricultural economists, 29 th of may 2015, Milan, Italy.

Jaletaa M, Kassie M, Tesfayea K, Teklewold T, Jenab PR, Marenyaa P, Erenstein O. 2016. Resource saving and productivity enhancing impacts of crop management innovation packages in Ethiopia. Journal of Agricultural Economics. 47: 513-522. DOI: https://dx.doi.org/10.1111/agec.12251

Kaleb K, Workneh N. 2016. Analysis of levels and determinants of technical efficiency of wheat producing farmers in Ethiopia. Afr. J. Agric. Res. 11(36): 339 - 3404. DOI https://dx.doi.org/10.5897/AJAR2016.11310

Kotu BH, Verkuijl H, Mwangi W, Tanner D. 2000. Adoption of improved wheat technologies in Adaba and Dodola Woredas of the Bale highlands, Ethiopia. Mexico, D.F.: International Maize and Wheat Improvement Center (CIMMYT) and Ethiopian Agricultural Research Organization (EARO)

Maddala GS. 1997. Limited dependent and quantitative variables in econometrics. Cambridge university press.

Mulatu E, Ibrahim OE, Bekele E. 2005. Policy changes to improve vegetable production and seed supply in Hararghe, eastern Ethiopia. Journal of Vegetable Sciences. 11(2): 81-106. Doi: http://dx.doi.org/10.1300/J484v11n02_08

NBE. 2016. Annual Report of the National Bank of Ethiopia (NBE) for the year 2014/15.

Nigussie D, Mengistu K, Haile D, Wole K, Tamiru A, Olkaba B, Solomon A, Samuel T. 2012. Participatory Rural Appraisal (PRA) for Gurawa, Haramaya, Kombolcha, and Habro Districts (Woredas) of East and West Hararghe Zones in Ethiopia.

Seymour G, Doss C, Marenya P, Meinzen-Dick R, Passarelli S. 2016. Women's empowerment and the adoption of improved maize varieties: evidence from Ethiopia, Kenya, and Tanzania. Selected paper prepared for presentation at the 2016 agricultural \& applied economics association annual meeting, Boston, Massachusetts, July 31-August 2.

Shiferaw B, Kassie M, Jaleta M, Yirga C. 2014. Adoption of improved wheat varieties and impacts on household food security in Ethiopia. Food Policy. 44: 272-284. DOI: http://dx.doi.org/10.1016/j.foodpol.2013.09.012

Spielman DJ, Byerlee D, Alemu D. Kelemework D. 2010. Policies to promote cereal intensifi cation in Ethiopia: The search for appropriate public and private roles. Food Policy. 35, 185-194. DOI: http://dx.doi.org/10.1016/j.foodpol.2009.12.002

Taffesse A, Dorosh P, Asrat S. 2012. Crop production in Ethiopia: Regional patterns and trends. Ethiopia strategy support program II. Washington DC: IFPRI.

Statista. 2017. Global wheat yield per hectare from 2010/2011 to 2025/2026 (in metric tons). (https://www.statista.com/statistics/ 237705/global-wheat-production/)

Tesfaye Z, Girma TD, Tanner H, Verkuijl AA, Mwangi W. 2001. Adoption of Improved Bread Wheat Varieties and Inorganic Fertilizer by Small Scale Farmers in Yelmana Densa and Farta Districts of Northwestern Ethiopia. Mexico, D.F.: Ethiopian Agricultural Research Organization (EARO) and International Maize and Wheat Improvement Center (CIMMYT).

Yigezu A, Chilot YT, Aden Aw-H. 2015. Modeling farmers' adoption decisions of multiple crop technologies: The case of barley and potatoes in Ethiopia. Paper presented on Int. conference of agricultural economists, 29 th of May 2015, Milan, Italy. 